\title{
Enhanced Sorption of Naphthalene onto a Modified Clay Adsorbent: Effect of Acid, Base and Salt Modifications of Clay on Sorption Kinetics
}

\author{
Chiedu N. Owabor*, Uzezi M. Ono, Aigbokhan Isuekevbo \\ Department of Chemical Engineering, University of Benin, Benin City, Benin \\ Email: "owabor4you@yahoo.com
}

Received February 1, 2012; revised March 5, 2012; accepted March 15, 2012

\begin{abstract}
This paper examined the influence of acid, base and salt modifications of clay on its rates of naphthalene adsorption. The modifiers used include hydrochloric acid $(\mathrm{HCl})$, citric acid, sodium hydroxide $(\mathrm{NaOH})$, ammonium hydroxide $\left(\mathrm{NH}_{4} \mathrm{OH}\right)$, sodium chloride $(\mathrm{NaCl})$ and zinc chloride $\left(\mathrm{ZnCl}_{2}\right)$. The results obtained showed that equilibrium adsorption of naphthalene from the bulk solution was attained at a faster rate using modified clay when compared with the unmodified clay. HCl-modified clay had the highest rate of adsorption with a surface area and porosity of $49.05 \mathrm{~mm}^{2}$ and $53.4 \%$. This was closely followed by $\mathrm{NaOH}$-modified clay while down the order was the $\mathrm{ZnCl}_{2}$-modified clay which had the least rate of adsorption with a surface area of $44.3 \mathrm{~mm}^{2}$ and porosity of $43.4 \%$. The implication of the retention time obtained from the equilibrium study is significant as it provides the bench mark for interplay between sorption and degradation for transport and transformation of contaminant solutes within the soil matrix.
\end{abstract}

Keywords: Modification; Cation-Exchange-Capacity; Natural Clay; Adsorbate; Surfactants

\section{Introduction}

This research work relates to the generation of equilibrium data on the adsorption of naphthalene through experiment using modified and unmodified clay. The process of adsorption has been described as one of the most important chemical processes in soils. It determines the quantity of plant nutrients, metals, pesticides and other organic chemicals retained on soil surfaces and is therefore one of the primary processes that affects the transport of nutrients and contaminants in soil. Successful predictions of the transport and fate of solutes in the subsurface is hinged on the availability of accurate transport parameters. Data on availability, transport and fate of contaminant solutes, which are limited, can be obtained from sorption studies such as the one conducted in this study and hence be utilized for the design of reactors for effective treatment process.

The process of adsorption creates a film of the adsorbate (the molecules or atoms being accumulated) on the surface of the adsorbent. It differs from absorption, in which a fluid permeates or is dissolved by a liquid or solid. The term sorption encompasses both processes, while desorption is the reverse of adsorption. It is a surface phenomenon [1,2].

*Corresponding author.
Various toxic chemicals such as polycyclic aromatic hydrocarbons, heavy metals, dyes, solvents have been discharged to the environment as industrial wastes, causing serious water, air and soil pollutions and they threaten the human health. Polycyclic aromatic compounds are continuously widely studied environmental subjects due to their potential carcinogenicity, mutageni-city or both. They are mainly emitted from combustion processes including engine exhaust, industrial processes, natural gas, domestic heating systems, barbecue, and smoke, incomplete combustion of fossil fuels, volcanic eruptions and forest fires [3-5]. The discharge of these toxic organic chemicals into water bodies causes harmful effects to the environment and treatment of the contaminated water as economically as possible has been a problem over time. However the use of sediment has become a viable alternative being naturally abundant, easily sourced and cheap.

The removal of these kinds of pollutants from the environment cannot be accomplished by using traditional methods. It is now extensively recognised that adsorption provides a feasible, effective method for the removal of pollutants from waste water [6,7]. Research interests in the use of sediments such as clay, loamy soil, silt, shale etc. as adsorbent for the purpose of adsorption are currently being advanced [8-12]. The wide usefulness of 
these kinds of adsorbents is as a result of their high chemical and mechanical stability, and a variety of surface and structural properties. The pore structure and chemical properties generally determine the adsorption ability of the clays [13].

The natural form of clay shows relative ineffectiveness as an adsorbent for neutral organic contaminants such as polycyclic aromatic hydrocarbons. The adsorptive properties of sepiolite for neutral polycyclic aromatic hydrocarbons can be greatly improved by replacing the neutral inorganic interlayer cations (sodium and calcium ions) with large organic cations of the long chain alkyl hydrocarbons $[14,15]$. These modified clays are called organoclays and have been effective in the removal of various neutral organic contaminants including naphthalene from aqueous solutions $[16,17]$. Clay and other layered silicate clays are naturally hydrophilic. This makes them poorly suited to mixing and interacting with most polymer matrices which are mostly hydrophobic.

A popular and relatively easy method of modifying the clay surface, making it more compatible with an organic matrix, is ion exchanging. The cations are not strongly bound to the clay surface, so small molecule cations can replace the cations present in the clay. By exchanging it with various organic cations, montmorillonite clay can be compatible with a wide variety of matrix polymers [18]. At the same time, the process of modification helps to separate the clay platelets so that they can be more easily intercalated and exfoliated [19,20].

This study therefore seeks to determine the role of acids, bases and salts on the performance of clay as an adsorbent in the removal of organic contaminants and at the same time, establish the adsorptive capabilities of both modified and unmodified clay.

\section{Materials and Methods}

\subsection{Materials}

Clay used in this study was obtained from Ikpoba River, Benin City, Edo State, Nigeria. On collection, stones and other heavy particles were removed from the clay sample. It was then sieved through a $220 \mu \mathrm{m}$ mesh size to remove the larger non-clay fractions from the clay. Clay obtained was shared into three portions. Each portion was modified with acid, base and salt.

Hydrochloric and citric acids, sodium and ammonium hydroxides, sodium and zinc chlorides used in this study were of analytical grade and obtained from the Chemical Engineering Laboratory, University of Benin, Benin City.

\subsection{Methods}

The clay samples (both modified and unmodified clay) were analyzed for the following parameters:

\subsection{1. pH Determination}

The soil $\mathrm{pH}$ was determined by using $10 \mathrm{~g}$ of clay sample into a $100 \mathrm{ml}$ beaker and $20 \mathrm{ml}$ of distilled water was added to the clay soil sample and stirred for $30 \mathrm{~min}$. The sample $\mathrm{pH}$ was measured with the $\mathrm{pH}$ meter.

\subsubsection{Bulk Density Determination}

The bulk density of the clay was determined according to the procedure described by (Ahmedna et al., 1997; Huerta-Pujol et al., 2010). $100 \mathrm{~g}$ of clay was placed in a 100 $\mathrm{ml}$ measuring cylinder, a little vibration was applied until no particle space and constant level of clay was noticed in the cylinder and the volume recorded.

$$
\text { Bulk density }(\mathrm{g} / \mathrm{dm})=\frac{\text { Weight of clay }}{\text { Volume }}
$$

\subsubsection{Surface Area Determination}

The surface area of the clay was determined by iodine adsorption method. The amount of aqueous solution was estimated by titrating a blank with standard thiosulphate solutions and compared with titrated values against iodine containing samples [21-23].

$$
\text { Iodine value }(\mathrm{mg} / \mathrm{g})=\frac{(\mathrm{B}-\mathrm{S}) \times \mathrm{M} \times 126.91}{\mathrm{~B} \times \mathrm{W}}
$$

$\mathrm{B}$ and $\mathrm{S}$ are the volumes of thiosulphate solution required for blank and sample titrations respectively, $\mathrm{W}$, the mass of activated carbon sample and $\mathrm{M}$, the concentration (mol/l) of iodide solute and 126.91, atomic mass of iodine. The iodine value was used to measure the surface area.

\subsubsection{Moisture Content Determination}

A sample of wet clay was weighed, put into a Karl Kolb oven (Heraeus Type) to dry at a temperature of $95^{\circ} \mathrm{C}$ for one hour, cooled and then weighed following the procedure of Ramulu (2003).

$$
\text { Percentage moisture }=\frac{\left(\mathrm{W}_{\mathrm{m}}-\mathrm{W}_{\mathrm{d}}\right)}{\mathrm{W}_{\mathrm{m}}} \times 100
$$

where $\mathrm{W}_{\mathrm{m}}$ and $\mathrm{W}_{\mathrm{d}}$ are weights of sample and dry sample respectively.

\subsubsection{Particle Density}

$20 \mathrm{~g}$ of oven dried soil was weighed into a measuring cylinder and after tapping the cylinder gently, the volume of the soil is recorded as $V_{1} .50 \mathrm{ml}$ of distilled water was added slowly through the ride of the cylinder to soak the sample thoroughly. The final soil and water volume was noted as $\mathrm{V}_{2}$, and the particle density calculated according to Equation (4) [24]:

$$
\text { Particle density }=\frac{\text { Weight of soil }(20 \mathrm{~g})}{\text { Volume of soil taken }}=\frac{\mathrm{W}}{\mathrm{V}_{2}-\mathrm{V}_{1}}
$$




\subsubsection{Modification of Clay Samples}

\subsubsection{Using Acid}

$200 \mathrm{ml}$ of $0.4 \mathrm{M}$ citric acid, and hydrochloric acid were added to two separate portions of $50 \mathrm{~g}$ prepared clay sample respectively. These were mixed in a magnetic stirrer for $3 \mathrm{hr}$ at $200 \mathrm{rpm}$. The samples were centrifuged at $1500 \mathrm{rpm}$ for $15 \mathrm{~min}$. The samples were then rinsed with $500 \mathrm{ml}$ of distilled water several times until they became neutral to litmus. The samples were then dried at $373 \mathrm{~K}$ in an oven [25,26].

\subsubsection{Using Base}

Two portions of the prepared clay sample were separately mixed in the ratio of $1 \mathrm{~g}$ to $5 \mathrm{ml}$ of $0.4 \mathrm{M}$ sodium hydroxide and ammonium hydroxide for $3 \mathrm{hr}$ at $200 \mathrm{rpm}$. The samples were centrifuged at $1500 \mathrm{rpm}$ for $15 \mathrm{~min}$. The samples were then rinsed with $500 \mathrm{ml}$ distilled water several times until they became neutral to litmus. The sample was then dried at $373 \mathrm{~K}$ in an oven [26-28].

\subsubsection{Using Salt}

Two portions of the prepared clay sample were separately mixed in the ratio of $1 \mathrm{~g}$ to $7 \mathrm{ml} 1 \mathrm{M}$ sodium chloride and zinc chloride at $303 \mathrm{~K}$ for $3 \mathrm{hr}$. The modified clay samples were then filtered and washed several times until they became neutral to litmus. Then the samples were dried at $373 \mathrm{~K}$ in the oven [29-31].

\subsubsection{Preparation of the Bulk Solution}

An aqueous solution of naphthalene was prepared by first dissolving $200 \mathrm{mg}$ of naphthalene in $100 \mathrm{ml}$ of ethanol before $900 \mathrm{ml}$ of water was added. The solution was properly stirred to obtain a homogeneous solution.

\subsubsection{Adsorption Studies}

The rate of adsorption of the various modified clay samples were determined from the uptake levels of naphthalene from aqueous solution in batch experiments before and after contact until adsorption equilibrium was reached in the various modified clay adsorbent [32]. $100 \mathrm{~g}$ of modified clay were mixed with $1000 \mathrm{ml}$ of aqueous solution of the adsorbate at room temperature. The slurry suspensions were sampled at intervals of $2 \mathrm{hr}$ and UV spectrophotometer was used for sample analysis and the values of absorbance recorded.

\section{Results and Discussion}

The results of the physico-chemical analysis of both the modified and unmodified natural clay samples are presented in Table $\mathbf{1}$.

The adsorption of naphthalene as shown in Figure $\mathbf{1}$ increased with increasing contact time and thereafter the

Table 1. Physico-chemical analysis of modified and unmodified clay.

\begin{tabular}{lccccccc}
\hline \multicolumn{1}{c}{ Parameters } & Unmodified & HCl modified & Citric acid modified & NaOH modified & $\mathrm{NH}_{4} \mathrm{OH}$ modified & $\mathrm{NaCl}_{\text {modified }} \mathrm{ZnCl}_{2}$ modified \\
\hline Bulk density $\left(\mathrm{g} / \mathrm{cm}^{3}\right)$ & 1.15 & 1.15 & 0.93 & 1.14 & 1.39 & 0.97 & 0.99 \\
Surface area $\left(\mathrm{mm}^{2}\right)$ & 46.52 & 50.05 & 48.15 & 48.10 & 46.00 & 47.35 & 44.30 \\
Particle density $\left(\mathrm{g} / \mathrm{cm}^{3}\right)$ & 1.70 & 1.67 & 1.55 & 1.75 & 0.95 & 2.13 & 1.85 \\
Moisture content (\%) & 4.25 & 4.1 & 4.15 & 4.1 & 4.21 & 3.95 & 3.85 \\
pH & 7.1 & 2.3 & 3.5 & 12.3 & 11.1 & 7.3 & 6.6 \\
Porosity (\%) & 45.9 & 54.60 & 46.8 & 49.1 & 45.5 & 44.5 & 43.4 \\
\hline
\end{tabular}

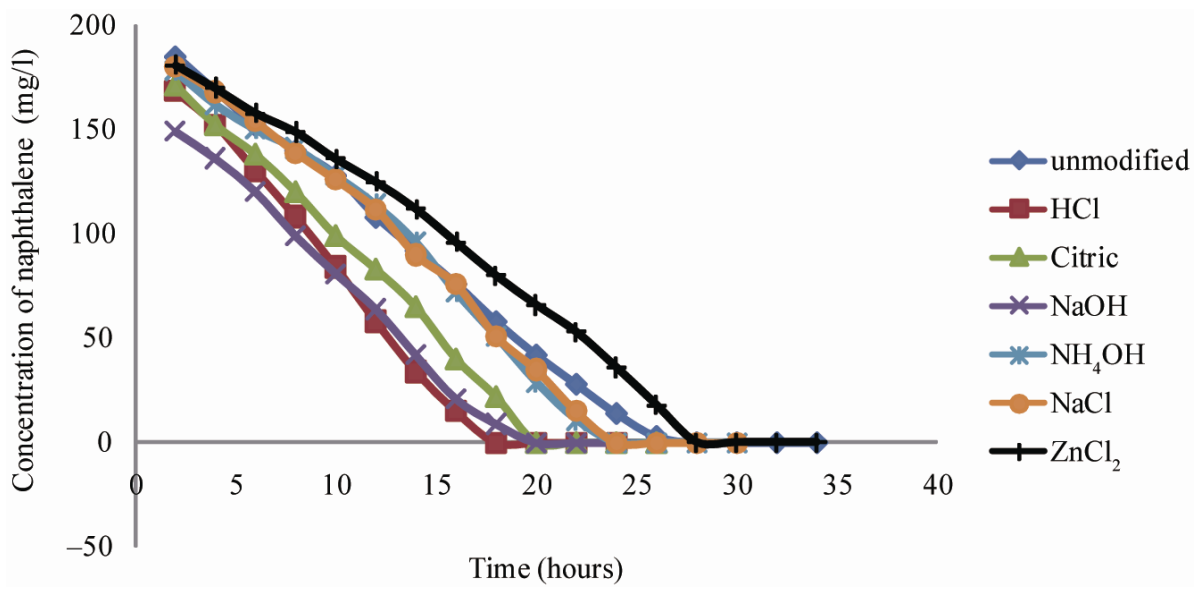

Figure 1. Variation of concentration with time for unmodified and modified clay samples. 
adsorption from the aqueous phase remained constant with time. The patterns of the curve affirm that adsorption is time dependent. This result is consistent with literature reports of Gök et al. (2008), Owabor et al. (2010), and also agrees with the adsorption kinetic theory which states that the higher the time, the more the amount of fluid adsorbed in the adsorbent (McCabe et al., 1993).

Laboratory results showed that adsorption of naphthalene from the bulk solution using unmodified clay took the longest time of 28 hours before equilibrium was attained. Upon modification with the acids, bases and salts used in this study, the rate of adsorption increased an indication that equilibrium would be attained at a faster rate when compared with the unmodified clay.

The unmodified natural clay and modified clay samples were used as adsorbent for the adsorption of naphthalene. Both unmodified and modified clay samples adsorbed the adsorbate at different rates from the bulk solution under the same experimental conditions. The result obtained suggests that the hydrophilic nature of clay may be responsible for why it did not to a large extent adsorb the organic compound.

From this study, modifying with strong acidic solutions as shown using $\mathrm{HCl}$ significantly increased the adsorptive capacity of natural clay used as adsorbent. This was closely followed by the bases. The effect of citric acid was minimal on the sorption capacity of clay and this could be attributed to weakness of the acid. In contrast, the performance of the salts modified clay were very poor as virtually all the parameters determined in this study which are used to assess sorption capacity were notably below the values obtained for the unmodified natural clay. The implication of this result is that modification with salts adds little or no value to natural clay.

The rates of adsorption for the different modified samples of clay were studied using the concentration-time plots. The profiles are as shown in Figure 1.

The profiles showed that adsorption proceeded at a very slow rate for the unmodified samples. Here the rate of depletion of the adsorbate from the bulk solution took a long time and equilibrium was observed to be attained at the 28th hour.

Modifying with $\mathrm{HCl}$ showed a tremendous improvement in the adsorptive capacity of the clay. The rate of depletion of naphthalene from the bulk solution was observed to have increased and equilibrium attained at the 18th hr. This capacity can be adduced to the fact that $\mathrm{HCl}$ modified clay had the highest surface area and porosity; two very important factors that affect the rate of adsorption by an adsorbent. The interaction of the acid with the clay may likely have enhanced the pores of the sediment, thereby increasing its surface area and improving the adsorptive power of the clay.
The citric acid modified clay was a poorer adsorbent compared to $\mathrm{HCl}$ modified clay. Adsorption proceeded at a slower rate and equilibrium was attained at the 20th hour. This variation could be attributed to the strength of the acid involved as well as the decreased surface area and lower porosity obtained (Table 1).

Sodium hydroxide modified clay showed relatively good capacity to adsorb naphthalene from the bulk solution when compared to the performance of the $\mathrm{HCl}$ modified clay. It was observed that equilibrium was attained in the 20th hour. This time was the same as that observed for citric acid and thus suggests that a strong base was capable of chemically modifying clay just as a weak acid.

Ammonium hydroxide modified clay, as observed from Figure 1, equally showed a slow rate of adsorption of naphthalene from the bulk solution. It took a longer time precisely $24 \mathrm{hr}$ to attain equilibrium.

Result in the case of sodium chloride modified clay showed that the rate of adsorption proceeded very slowly as compared with those of $\mathrm{HCl}$ and $\mathrm{NaOH}$ modified clay. As was observed with ammonium hydroxide, equilibrium was attained in 24 hours.

Zinc chloride modified clay presented in the profile of Figure 1 showed no difference in comparison with the unmodified natural clay. Equilibrium was reached at the same time observed for the unmodified clay i.e. 28 hours. Both sodium and zinc chlorides, showed comparatively slow rate of adsorption, which can be attributed to the low porosity and smaller surface area of the salt modified clay given in Table $\mathbf{1 .}$

Generally, from the equilibrium time, sodium hydroxide compared favourably with citric acid and this can be explained from the standpoint of electro reactivity within the electrochemical series. Sodium hydroxide as a very strong base has a higher reactivity than a weak acid which in this case is represented by citric acid. This argument can again be advanced for the observed equilibrium time (28 hours) of zinc chloride and unmodified clay and ammonium hydroxide and sodium chloride (24 hours). Though ammonium hydroxide is a base and expectedly more corrosive than a salt, the equilibrium time from this study significantly showed that sodium chloride had a higher cation exchange capacity. Zinc is low in the electrochemical series and hence weak in electro positivity. It is again worthy to note that despite the fact that the molarity of the acids and alkalis were $0.4 \mathrm{M}$ each, and the salts $\left(\mathrm{NaCl}\right.$ and $\left.\mathrm{ZnCl}_{2}\right)$ were $1.0 \mathrm{M}, \mathrm{HCl}$ showed the highest adsorption potential. This affirms that salts are poor modifiers. The effects of $\mathrm{HCl}, \mathrm{NaOH}, \mathrm{NaCl}$ and $\mathrm{ZnCl}_{2}$ on the clay involved the exchange of their cations with those of the clay. This interaction predisposes the surface to adsorption. The physico-chemical analyses of the modified clay which gave a higher surface area and 
porosity when modified with $\mathrm{HCl}$ than those of the alkalis and salts, suggest that the cation exchange capacity of clay with $\mathrm{HCl}$ was better compared to $\mathrm{NaOH}$ and the salts.

The implication of modifying natural clay with $\mathrm{HCl}$ and $\mathrm{NaOH}$ is that it speeds up the hydraulic conductivity of the adsorbent for the adsorbate (naphthalene), an action which results from the fact that the small pore sizes tends to hold the adsorbates to its particles. Deductions from the physicochemical analysis further showed that salts reduced the moisture content and increased the maximum density and hence the particle density of the soil.

\section{Conclusions}

The adsorptive capacity of natural clay increased upon modification in the following order: salt $<$ base $<$ acid. Salts which are neutral to litmus did not show prospects as a modifying agent for clay. The dynamic behavior for the adsorption of naphthalene onto natural clay with various modifying agents increased to a large extent with increasing surface area and porosity of the modifier.

The obtained results indicate that modified clay, especially acid-modified clay can be a promising adsorbent for the removal of polycyclic aromatic hydrocarbons such as naphthalene from contaminated water.

\section{REFERENCES}

[1] J. F. Richardson, J. H. Harker and J. R. Backhurst, "Chemical Engineering: Particle Technology and Separation Processes," 5th Edition, Butterworth Heinemnn, India, 2003.

[2] W. L. McCabe, J. C. Smith and P. Harriot, "Unit Operations of Chemical Engineering,” 7th Edition, McGraw Hill, New York, 2005.

[3] R. C. Zielke and T. J. Pinnavaia, “Toxicants: Binding of Chlorophenols to Pillared, Delaminated, and HydroxyInterlayered Smectites," Clays and Clay Minerals Journal, Vol. 36, No. 5, 1988, pp. 403-408. doi:10.1346/CCMN.1988.0360504

[4] R. Goldman, L. Enewold, E. Pellizzari, J. B. Beach, E. D. Bowman, S. S. Krishnan and P. G. Shields, "Smoking Increases Carcinogenic Polycyclic Aromatic Hydrocarbons in Human Lung Tissue,” Cancer Research Journal, Vol. 61, 2001, pp. 6367-6371.

[5] M. Ghiaci, A. Abbaspur, R. Kia and F. Seyedeyn-Azad, "Equilibrium Isotherms Studies for the Sorption of Benzene, Toluene and Phenol onto Organo-Zeolites and AsSynthesized MCM-41," Separation and Purification Technology, Vol. 40, No. 3, 2004, pp. 217-229. doi:10.1016/j.seppur.2004.03.001

[6] A. M. Mastral, T. Garcia, R. Murillo, M. S. Callen, M. V. Narvarro and J. Galban, “Assessment of Phenanthrene Removal from Hot Gas by Porous Carbons,” Energy Fuels, Vol. 15, No. 1, 2001, pp. 1-7. doi:10.1021/ef000116g
[7] Ö. Gök, S. A. Özcan and A. Özcan, “Adsorption Kinetics of Naphthalene onto Organo-Sepiolite from Aqueous Solutions,” Desalination, Vol. 220, No. 1-3, 2008, pp. 96107. doi:10.1016/j.desal.2007.01.025

[8] J. P. Chen, S. Wu and K. H. Chong, "Surface Modification of a Granular Activated Carbon by Citric Acid for Enhancement of Copper Adsorption,” Carbon, Vol. 41, No. 10, 2003, pp. 1979-1986. doi:10.1016/S0008-6223(03)00197-0

[9] M. Khalid, G. Joly, A. Renaud and P. Magnoux, "Removal of Phenol from Water by Adsorption Using Zeolites Bain,” Industrial \& Engineering Chemistry Research, Vol. 43, No. 17, 2004, pp. 5275-5280. doi:10.1021/ie0400447

[10] A. S. Özcan and A. Özcan, “Adsorption of Acid Dyes from Aqueous Solutions onto Acid-Activated Bentonite,” Journal of Colloid and Interface Science, Vol. 276, No. 1, 2004, pp. 39-46. doi:10.1016/j.jcis.2004.03.043

[11] A. Özcan and A. S. Özcan, "Adsorption of Acid Red 57 from Aqueous Solutions onto Surfactant-Modified Sepiolite,” Journal of Hazardous Materials, Vol. 125, No. 1-3, 2005, pp. 252-259. doi:10.1016/j.jhazmat.2005.05.039

[12] W. T. Tsai, C. W. Lai and T. Y. Su, “Adsorption of Bisphenol-A from Aqueous Solution onto Minerals and Carbon Adsorbents,” Journal Hazardous Materials, Vol. 134, No. 1-3, 2006, pp. 169-175. doi:10.1016/j.jhazmat.2005.10.055

[13] R. S. Juang, S. H. Lin and K. H. Tsao, "Mechanism of Sorption of Phenols from Aqueous Solutions onto Surfactant-Modified Montmorillonite,” Journal of Colloid Interface Science, Vol. 254, No. 2, 2002, pp. 234-241. doi:10.1006/jcis.2002.8629

[14] S. Y. Lee and S. J. Kim, “Adsorption of Naphthalene by Hdtma Modified Kaolinite and Halloysite,” Applied Clay Science, Vol. 22, No. 1-2, 2002, pp. 55-63. doi:10.1016/S0169-1317(02)00113-8

[15] C. F. Chang, C. Y. Chang, K. H. Chen, W. T. Tsai, J. L. Shie and Y. H. Chen, "Adsorption of Naphthalene on Zeolite from Aqueous Solution,” Journal of Colloid and Interface Science, Vol. 277, No. 1, 2004, pp. 29-34. doi:10.1016/j.jcis.2004.04.022

[16] J. M. Hwu, G. J. Jiang, Z. M. Gao, W. Xie and W. P. Pan, "The Characterization of Organic Modified Clay and ClayFilled PMMA Nanocomposite,” Journal of Applied Polymer Science, Vol. 83, No. 8, 2002, pp. 1702-1710.

[17] S. A. Boyd, M. M. Mortland and C. T. Chiou, "Sorption Characteristics of Organic Compounds on Hexadecyl Trimethy-Ammonium-Smectite," Soil Science Society of America Journal, Vol. 52, No. 3, 1988, pp. 652-657. doi:10.2136/sssaj1988.03615995005200030010x

[18] N. Xu, C. Christodoulatos and W. Braida, "Adsorption of Molybdate and Tetrathiomolybdate onto Pyrite and Geothite: Effect of $\mathrm{pH}$ and Competitive Anions," Chemosphere, Vol. 62, No. 10, 2006, pp. 1726-1735. doi:10.1016/j.chemosphere.2005.06.025

[19] K. M. Spark and R. S. Swift, "Effect of Soil Composition and Dissolved Organic Matter on Pesticside Sorption," Science of the Total Environment, Vol. 298, No. 1-3, 2002, pp. 147-161.

[20] X. Wu, B. Xiao, R. Li, C. Wang, J. Huang and Z. Wang, 
"Mechanisms and Factors Affecting Sorption of Microcystins onto Natural Sediments," Environmental Science \& Technology, Vol. 45, No. 7, 2011, pp. 2641-2647. doi:10.1021/es103729m

[21] M. Ahmedna, M. Johnson, S. J. Clarke, W. E. Marshall, and R. M. Reo, "Potential of Agricultural By-Products Based Activated Carbon for Use in Raw Surge Decolorization," Journal of the Science of Food and Agriculture, Vol. 75, No. 1, 1997, pp. 117-124. doi:10.1002/(SICI)1097-0010(199709)75:1<117::AID-JS FA850>3.0.CO;2-M

[22] O. Huerta-Pujol, M. Soliva, F. X. Martinez-Farre, J. Valero and M. Lopez, "Bulk Density Determination as a Single and Complementary Tool in Composting Process Control,” Bioresource Technology, Vol. 101, No. 3, 2010, pp. 995-1001. doi:10.1016/j.biortech.2009.08.096

[23] J. A. Lori, A. O. Lawal and E. J. Ekaem, "Characterisation and Optimization of Deferration of Kankara Clay," Journal of Engineering and Applied Sciences, Vol. 2, No. 5, 2007, pp. 60-74.

[24] U. S. Sree Ramulu, "Principles in the Quantitative Analysis of Water, Fertilizers, Plant and Soils," Scientific Publishers, India, 2003.

[25] W. E. Marshall, L. H. Wartall, D. E. Boler, M. M. Johns, and C. A. Tolea, "Enhanced Metal Adsorption by Soyabeans Hulls Modified with Citric Acids," Bioresource Technology, Vol. 69, No. 3, 1999, pp. 263-268.

[26] A. Gajo and B. Loret, "The Mechanics of Active Clays
Circulated by Salts, Acids and Bases,” 2007. http://www.unitn.it/ricerca/publicazioni.htm

[27] P. Malakul, K. R. Srinivasan and H. Y. Wang, "Metal Toxicity Reduction in Naphthalene Biodegradation by Use of Metal-Chelating Adsorbents," American Society of Microbiology, Vol. 64, No. 11, 1998, pp. 4610-4613.

[28] J. Q. Jiang and C. Cooper, "The Removal of Humic Substance with Modified Clay Adsorbents," Environ Engineering Science, Vol. 20, No. 6, 2003, pp. 581-586. doi:10.1089/109287503770736096

[29] M. E. Chukwuedo and F. E. Okieimen, "Enhanced Metal Adsorption by Groundnut Husks Modified with Citric Acid,” Journal of Chemical Society of Nigeria, Vol. 33, No. 2, 2008, pp. 50-53.

[30] T. Abood, A. B. Kasa and Z. B. Chik, "Stabilization of Silt Clay Soil Using Chloride Compounds,” Journal of Engineering Science \& Technology, Vol. 2, No. 1, 2007, pp. 102-110.

[31] M. F. Delbem, S. V. Ticiane, R. V. Francisco and R. D. Nicole, "Modification of a Brazilian Smectite Clay with Different Ammonium Salts," Química Nova, Vol. 33, No. 2, 2010, pp. 309-315. doi:10.1590/S0100-40422010000200015

[32] C. N. Owabor, S. E. Ogbeide and A. A. Susu, “Adsorption and Desorption Kinetics of Naphthalene, Anthracene and Pyrene in Soil Matrix,” Petroleum Science and Technology, Vol. 28, No. 5, 2010, pp. 504-514. doi:10.1080/10916460802108546 